\title{
LETTERS
}

\section{Conspicuous synovial lymphatic capillaries in juvenile idiopathic arthritis synovitis with rice bodies}

\section{E Rovenska, S Sturtina, O Greguska, L Pravda, J Rovensky}

$\mathrm{T}$ e paper of Mohr discussing the development of rice bodies with apatite crystals in fibrinous debris synovitis in rheumatoid arthritis ${ }^{1}$ prompted us to describe our recent morphological findings.

During synovectomy in a 33 year old woman with a longlasting systemic form of juvenile idiopathic arthritis (JIA) a large number of rice bodies and numerous synovial villi connected to the synovial membrane (SM) by very thin stalks were visible in the joint space (JS). Light microscopy of paraffin sections showed that the villi contained fibrin and had degenerated. In the SM, mononuclear infiltration, neoangiogenesis, intimal layer hyperplasia, and fibrin at the synovial surface were found. Light microscopy of serial semithin resin sections enabled a distinction to be made between lymphatic capillaries (LC). Prominent LC were found under villous fibrin (fig lA). In connective tissue around the LC, macrophages were seen. Cells and debris were rarely seen inside the lumina of the LC (fig 1B). LC were also seen in areas of the SM not covered with fibrin (fig lC). These LC were situated in the subintimal connective tissue and were often surrounded by numerous mononuclear cells. In some of these LC, cells (mostly lymphocytes) were found.

Kuhns presented a detailed morphological study of lymphatic drainage of synovial joints in rabbits. ${ }^{2} \mathrm{He}$ discovered that inflammation in the synovial tissue decreased the ability of LC to absorb material larger than that of molecular size and presumed that persistent inflammation was, to a certain extent, dependent on the non-functioning of the lymphatic vessels. Later, Pullinger and Florey proved that LC proliferated in acute inflammation and repair. ${ }^{3}$ They demonstrated that LC proliferated also in chronic inflammation induced in the skin of mice, and emphasised that debris was removed from the damaged areas by the LC, either directly or by phagocytic cells. Recently, in rheumatoid arthritic synovium, debris and cells were seen inside the lumina of LC and, moreover, endothelial microvalves were visualised in the walls of the LC by transmission electron microscopy. ${ }^{4}$

Endothelial microvalves of LC probably have an important role in drainage of excessive tissue fluid, allowing cells and debris to be removed from SM connective tissue spaces into the lymph. The LC are an integral part of connective tissue, in which prelymphatic tissue channels have been described. ${ }^{5}{ }^{6}$ In the patient reported in this paper, fibrin deposition and mononuclear infiltration may have blocked part of the prelymphatic tissue channels in the SM, thus reducing the drainage of the JS. This might have contributed to the formation of rice bodies in synovial fluid (SF).

Rice bodies in rheumatoid SF contain mononuclear cells, mostly macrophagic in appearance. ${ }^{7}$ Accumulation of rice bodies in the JS may contribute to increased cytokine levels in the SF. It is known that SF cytokines can modulate the level of vascular endothelial growth factor (VEGF) secretion. ${ }^{8}$ VEGF-C and D were shown to stimulate lymphangiogenesis. ${ }^{9}$
Recently, mature VEGF-C was found in rheumatoid arthritis synovial tissue. ${ }^{10}$
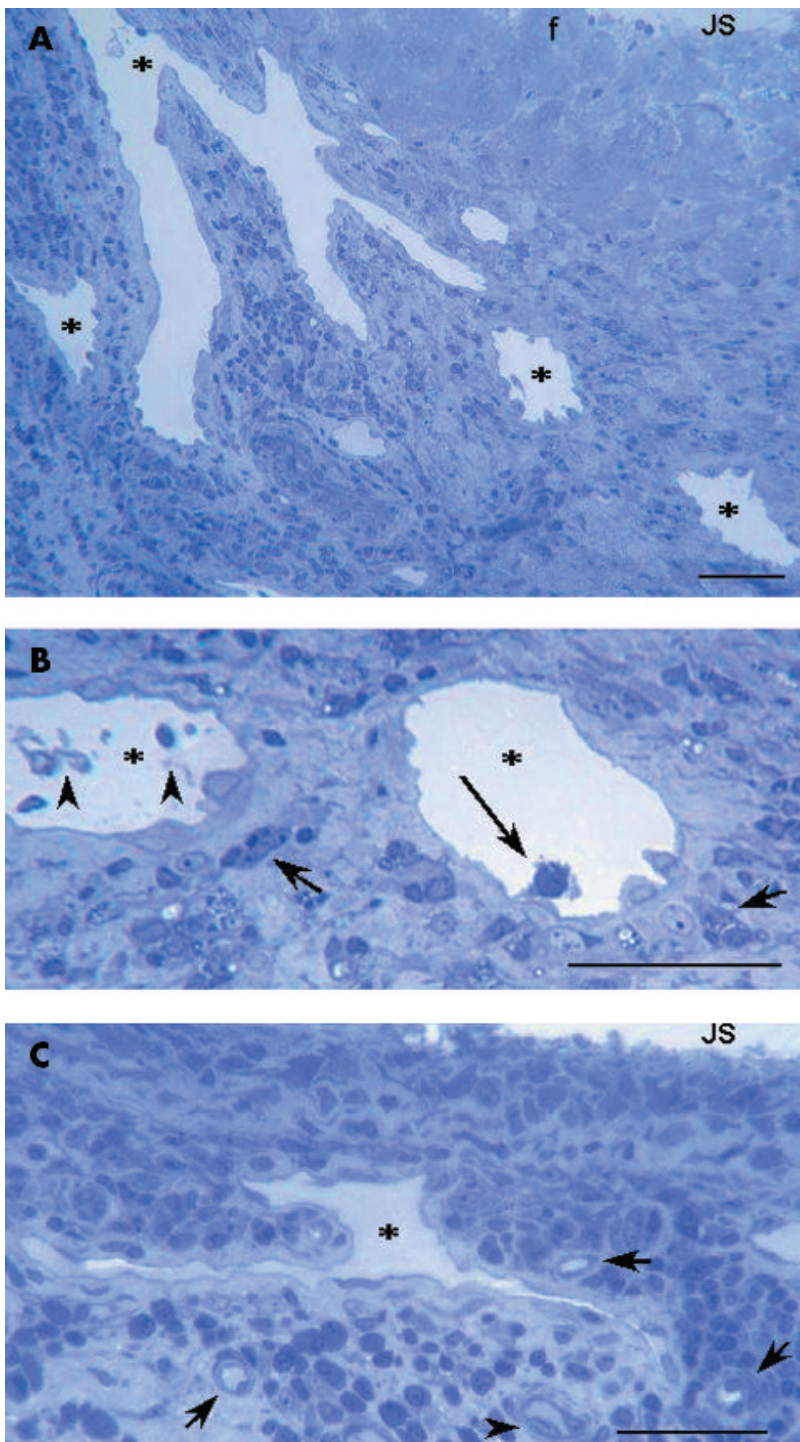

Figure 1 Synovial LC (asterisks) in semi-thin resin sections stained with toluidine blue. (A) LC in the SM area covered with fibrinous material ( $f$ ). Walls of the LC are composed of endothelial cells only. (B) Mononuclear phagocytes (arrows) in the vicinity of the LC. One phagocyte (large arrow) and debris (arrowheads) are visualised inside the lumina of the LC. (C) Large LC with an irregular shaped lumen surrounded by numerous mononuclear cells, situated in the sublining connective tissue of the SM under the intimal layer showing hyperplasia. Some blood capillaries (arrows) and a venule (arrowhead) are also visualised. JS, joint space. Scale bars $=100 \mu \mathrm{m}$. 
Our observation of conspicuous LC suggests that lymphangiogenesis may occur in JIA synovitis. In chronic synovitis, neogenesis of LC seems to be aimed at improving drainage and thus promoting homoeostasis in the JS.

\section{Authors' affiliations \\ E Rovenska, S Stvrtina, O Greguska, L Pravda, J Rovensky, National Institute of Rheumatic Diseases, Piestany, Slovakia \\ S Strrtina, Faculty of Medicine, Comenius University, Bratislava, Slovakia}

Correspondence to: Dr E Rovenska, National Institute of Rheumatic Diseases Nabr I Krasku 4 Piestany, Slovakia 921 12; rovenska@vurch.sk

Accepted 7 April 2004

\section{REFERENCES}

1 Mohr W. On the origin of rice bodies with apatite crystals. Ann Rheum Dis 2003;62:910-11.
2 Kuhns JG. Lymphatic drainage of joints. Arch Surg 1933;27:345-91

3 Pullinger BD, Florey HW. Proliferation of lymphatics in inflammation. J Pathol 1937:45: 157-70.

4 Rovenská E, Rovenská E, Neumüller J. Structure of synovial lymphatic capillaries in rheumatoid arthritis and juvenile idiopathic arthritis. Int J Tissue React 2003;25:29-39.

5 Casley-Smith JR. The fine structure of the microvasculature in inflammation. In: Microcirculation in inflammation. Basel: Karger, 1979, 17, 36-53.

6 Hauck G. The connective tissue space in view of the lymphology. Experientia 1982;38:1121-2.

7 Gálvez J, Sola J, Ortuño G, Vincente J, Mesa-del-Castillo J, Vincente V, et al. Microscopic rice bodies in rheumatoid synovial fluid sediments. J Rheumatol 1992;19:1851-8.

8 Bottomley MJ, Webb NJ, Watson CJ, Holt PJ, Freemont AJ, Brenchley PE. Peripheral blood mononuclear cells from patients with rheumatoid arthritis spontaneously secrete vascular endothelial growth factor (VEGF): specific upregulation by tumour necrosis factor-alpha (TNF-alpha) in synovial fluid. Clin Exp Immunol 1999;117:171-6.

9 Karkkainen MJ, Jussila L, Ferrel RE, Finegold DN, Alitalo K. Molecular regulation of lymphangiogenesis and targets for tissue oedema. Trends $\mathrm{Mol}$ Med, $2001 ; 7,18-22$.

10 Wauke K, Nagashima M, Ishiwata T, Asano G, Yoshino S. Expression and localization of vascular endothelial growth factor- $C$ in rheumatoid arthritis synovial tissue. J Rheumatol 2002;29:34-8.

\title{
Periostitis as the initial manifestation of systemic vasculitis
}

\author{
P M Aries, M Reuter, P Lamprecht, W L Gross
}

$\mathrm{T}$ he greatest challenge in diagnosing vasculitis is the diversity of its clinical presentation. Awareness of the heterogeneity of uncommon manifestations can be decisive for the course of the disease.

\section{CASE REPORT}

We report on a patient presenting with periostitis as the initial manifestation of systemic vasculitis. A 38 year old female patient complained about progressively painful swelling and reddening of the distal right lower leg for several weeks. The patient had been healthy until then and had no history of arterial or venous insufficiency. She presented at hospital with reduced pulses and a severe compartment syndrome of the tibialis anterior compartment. An $x$ ray examination showed typical signs of periostitis with periostal new bone formation (figs $1 \mathrm{~A}$ and $\mathrm{B}$ ).

Fasciotomy was done instantly and a periostal biopsy specimen was taken. Histopathological examination disclosed necrotising arteritis of small and medium sized arteries with polymorph neutrophilic infiltration of all layers of the vascular wall. Further investigation showed signs of systemic inflammation with a raised erythrocyte sedimentation rate $(30 \mathrm{~mm} / \mathrm{lst} \mathrm{h}), \mathrm{C}$ reactive protein $(30 \mathrm{mg} / \mathrm{l})$, and leucocytosis $\left(12 \times 10^{9} / 1\right)$. Other serological markers were negative, likewise c- and pANCA and ANCA enzyme linked immunosorbent assay (ELISA). Hepatitis B and C were excluded. An apparently recent complete and singular occlusion of the A. tibialis anterior was demonstrated by angiography. Immunosuppressive treatment with methotrexate ( $10 \mathrm{mg} /$ week, po) and oral prednisolone ( $10 \mathrm{mg} /$ day) was started.

The patient was consecutively referred to our department because of recurrent painful swelling of the right lower leg and the development of scleritis, arthritis, and sensory peripheral neuropathy. Additionally, several other symptomatic arterial stenoses of the major aortic branches (A. subclavia, A. vertebralis, A. femoralis) were detected by angiography. According to the nomenclature of the Chapel Hill Consensus Conference, the patient's disease was diagnosed as polyarteritis nodosa. ${ }^{1}$ Treatment was switched to cyclophosphamide (the so-called "NIH standard": cyclophosphamide $2.0 \mathrm{mg} / \mathrm{kg}$ body weight per day with daily prednisolone $\mathrm{po}^{2}$ ). After induction of remission, treatment was switched to azathioprine. Follow up bone radiography disclosed a moderate reduction of the new periostal bone formation and clinical remission was maintained at a 3 year follow up.

\section{DISCUSSION}

The patient presented initially with an unusual manifestation of systemic vasculitis. Vasculitis restricted to the local vascular region may be the initial manifestation of systemic vasculitis. In this particular case, vasculitis of the periosteum might have induced local hypoxia of the bone, with subsequent release of bone derived growth factors and manifestation of periostitis. ${ }^{3}$ Periostitis is seen in many other conditions but is not common in necrotising vasculitis. It was described for the first time by Lovell and Scott in 1956. ${ }^{4}$ Until now only a few cases of periostitis in patients with polyarteritis nodosa have been reported; remarkably, the lower extremities were affected in all cases. ${ }^{5-7}$ However, periostitis has also been reported in other forms of systemic vasculitis. ${ }^{8-10}$ Most cases responded well to glucocorticoids. In refractory cases other cytotoxic treatment like methotrexate, azathioprine, or cyclophosphamide may be useful.

Thus, as demonstrated by this case, in patients with painful swelling of the lower limb, clinicians should consider periostitis as an unusual manifestation of systemic vasculitis.

\section{Authors' affiliations}

P M Aries, P Lamprecht, W L Gross, Universitätsklinikum Schleswig Holstein, Campus Lübeck, Poliklinik für Rheumatologie und Rheumaklinik Bad Bramstedt, Germany 

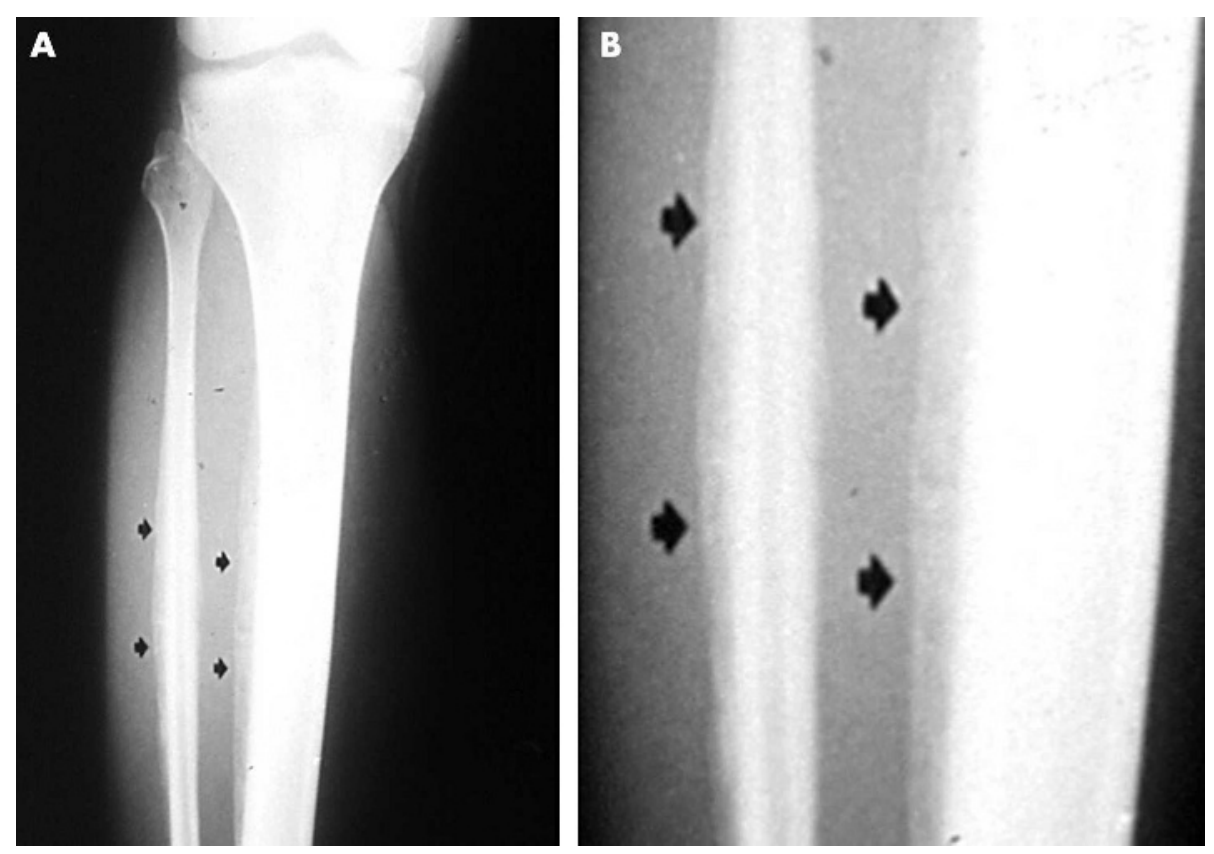

Figure 1 (A) Bone radiography of the right lower leg with periostal new bone formation (arrow). (B) A magnified view.

M Reuter, Universitätsklinikum Schleswig-Holstein, Campus Kiel, Klinik für Diagnostische Radiologie, Bad Bramstedt, Germany

Correspondence to: Dr P Aries, Rheumaklinik Bad Bramstedt, OskarAlexander Strasse 26, 24576 Bad Bramstedt, Germany; aries@rheuma-zentrum.de

Accepted 6 July 2004

\section{REFERENCES}

1 Jenette JC, Falk RJ, Andrassy K, Bacon PA, Churg J, Gross WL, et al. Nomenclature of systemic vasculitides. Arthritis Rheum 1994;37:187-92.

2 Fauci AS, Haynes BF, Katz P, Wolff SM. Wegener's granulomatosis: prospective clinical trial and therapeutic experience with 85 patients for 21 years. Ann Intern Med 1983;98:76-85.
3 Astudillo LM, Rigal F, Couret B, Arlet-Suau E. Localized polyarteritis nodosa with periostitis. J Rheumatol 2001;28:2758-9.

4 Lovell R, Scott G. Hypertrophic osteoarthropathy in polyarteritis. Ann Rheum Dis 1956;15:46-50.

5 Saville PD. Polyarteritis nodosa with new bone formation. J Bone Surg Br 1956;38:327-33.

6 Woodward AH, Andreini PH. Periostal new bone formation in polyarteritis nodosa: a syndrome involving the lower extremities. Arthritis Rheum 1974;17:1017-25.

7 Brandrup F, Petersen EM, Hansen BF. Localized polyarteritis nodosa in the lower limb with new bone formation. Acta Dermatol Venerol 1980;60:182-4

8 Korkmaz C, Efe B, Tel N, Kabukcuoglu S, Erenoglu E. Sarcoidosis with palpable nodular myositis, periostitis and large vessel vasculitis stimulating Takayasus arteritis. Rheumatology (Oxford) 1999;38:287-8.

9 Glickstein M, Neustadter L, Dalinka M, Kricum M. Periostal reaction in systemic lupus erythematosus. Skeletal Radiol 1986;15:610-12.

10 Short DJ, Webley M. Periostal new bone formation complicating juvenile polyarthritis nodosa. J Roy Soc Med 1984;77:325-7.

\section{Presence of rheumatoid factor and antibodies to citrullinated peptides in systemic lupus erythematosus}

\section{E A Hoffman, I Peene , L Cebecauer, D Isenberg, T W J Huizinga, A Union, L Meheus, K De Bosschere, F Hulstaert, E M Veys, F De Keyser}

$R^{h}$ heumatoid factor (RF) is found commonly in patients with systemic lupus erythematosus (SLE), and has been associated with a more benign disease course. ${ }^{12}$ Anticitrullinated peptide antibodies (ACPA) are more specific for rheumatoid arthritis (RA)..$^{3-5}$ Several assays for ACPA detection have been developed: among others, an enzyme linked immunosorbent assay (ELISA) for anti-cyclic citrullinated peptide (anti-CCP) antibodies ${ }^{3}$ and a line immunoassay (LIA) for antibodies to peptide A (pepA) and peptide B (pepB), two synthetic citrullinated peptides. ${ }^{4}$ Few reports exist about the presence of ACPA in SLE. Although patients with SLE are often part of the control group when determining the specificity of ACPA for RA, SLE alone is seldom studied. Mediwake et al found that 3/66 patients with SLE were positive for anti-CCP1 antibodies; two of them had erosive arthritis. ${ }^{6}$ We investigated the presence of RF and three different ACPA (anti-CCP, anti-pepA, and anti-pepB antibodies) in SLE.

Two hundred and thirty five patients with SLE, meeting American College of Rheumatology (ACR) revised criteria for classification of $\mathrm{SLE},{ }^{78}$ were prospectively included in four European centres. The study investigated associations between symptoms and specific antinuclear reactivities and has been reported elsewhere.' Serum was available for further analysis in 201 patients. The male to female ratio was 25:176. The mean age was 40 years. The study was 
Table 1 Characteristics of ACPA positive patients with SLE

\begin{tabular}{|c|c|c|c|c|c|c|c|c|c|}
\hline Patient No & & Anti-CCP & Anti-PepA & $\begin{array}{l}\text { Anti- } \\
\text { PepB }\end{array}$ & $\begin{array}{l}\text { Fine antinuclear } \\
\text { reactivities }\end{array}$ & SE & $\mathbf{R x}$ & RA crit & Clinical signs \\
\hline 1 & 1280 & 186 & $3+$ & $3+$ & SSB, Ro60 & 0 & - & - & $\begin{array}{l}\text { Arthritis, proteinuria, leucopenia, } \\
\text { lymphopenia }\end{array}$ \\
\hline 2 & 640 & 9 & - & $1+$ & RNP-C & 0 & - & + & $\begin{array}{l}\text { Butterfly rash, photosensitivity, arthritis, } \\
\text { lymphopenia }\end{array}$ \\
\hline 3 & 0 & 168 & - & - & dsDNA & NA & NA & NA & $\begin{array}{l}\text { Butterfly rash, oral ulcers, arthritis, } \\
\text { proteinuria, cellular casts }\end{array}$ \\
\hline 4 & 0 & 83 & - & - & SmB, dsDNA & NA & NA & NA & $\begin{array}{l}\text { Butterfly rash, photosensitivity, oral ulcers, } \\
\text { arthritis, pleuritis, leucopenia }\end{array}$ \\
\hline 5 & 80 & 2 & - & $1+$ & Histones, dsDNA & NA & NA & NA & $\begin{array}{l}\text { Butterfly rash, arthritis, proteinuria, cellular } \\
\text { casts }\end{array}$ \\
\hline 6 & 0 & 76 & - & - & $\begin{array}{l}\text { SmB, RNP-A, RNP-C, } \\
\text { ribosomal P, histones }\end{array}$ & 1 & NA & + & $\begin{array}{l}\text { Arthritis, pericarditis, pleuritis, proteinuria, } \\
\text { thrombopenia, leucopenia, haemolytic } \\
\text { anaemia }\end{array}$ \\
\hline 7 & 40 & 64 & - & - & $\begin{array}{l}\text { SmD, SmB, RNP-C, RNP- } \\
70 k \text {, ribosomal P }\end{array}$ & & NA & - & $\begin{array}{l}\text { Butterfly rash, photosensitivity, pleuritis, } \\
\text { arthritis, leucopenia }\end{array}$ \\
\hline 8 & 0 & 58 & - & - & Negative & 0 & NA & - & $\begin{array}{l}\text { Butterfly rash, photosensitivity, lymphopenia, } \\
\text { leucopenia }\end{array}$ \\
\hline 9 & 320 & 110 & - & - & $\begin{array}{l}\text { SmB, RNP-70k, RNP-A, } \\
\text { RNP-C, histones, dsDNA }\end{array}$ & 0 & - & + & Arthritis, leucopenia \\
\hline 10 & 320 & 78 & $1+$ & $1+$ & $\begin{array}{l}\text { SmB, RNP-70k, RNP-A, } \\
\text { RNP-C }\end{array}$ & 0 & + & + & Arthritis, pleuritis, lymphopenia \\
\hline 11 & 80 & 56 & - & - & $\begin{array}{l}\text { RNP-A, histones, } \\
\text { ribosomal P }\end{array}$ & 1 & - & - & $\begin{array}{l}\text { Butterfly rash, photosensitivity, lymphopenia, } \\
\text { leucopenia }\end{array}$ \\
\hline 12 & 640 & 52 & - & - & RNP-70k, RNP-A & 0 & + & + & $\begin{array}{l}\text { Butterfly rash, oral ulcers, arthritis, cellular } \\
\text { casts, proteinuria, lymphopenia, leucopenia }\end{array}$ \\
\hline 13 & 320 & $>1600$ & $2+$ & $2+$ & Ro60 & 0 & + & + & Butterfly rash, arthritis, lymphopenia \\
\hline
\end{tabular}

approved by the local ethics committees. Informed consent was obtained from all patients.

Fine antinuclear reactivities were determined with INNOLIA-ANA Update (Innogenetics, Ghent, Belgium) and by indirect immunofluorescence on Crithidia luciliae. RF was detected using the latex fixation method (Becton Dickinson, Sparks, Maryland, USA). Titres $\geqslant 160$ were considered positive, which corresponds to a specificity for RA of $95.9 \%$ in an independent control cohort, consisting of 146 patients with rheumatic complaints but no RA (data not shown). Anti-CCP2 antibodies were detected by ELISA (Immunoscan RA, mark 2, Eurodiagnostica, Arnhem, Netherlands). A cut off value of $42 \mathrm{U} / \mathrm{ml}$ was used. Anti-pepA and anti-pepB antibodies were detected by a research LIA (Innogenetics). ${ }^{4}$ During each run, a strip was developed using a control serum, providing a cut off intensity for each antigen line. In the control population mentioned earlier, all three ACPA had a specificity of at least $98.5 \% .^{5}$ The RA associated HLA-DR shared epitope (SE) was determined with INNO-LiPA (Innogenetics).

$\chi^{2}$ Tests were used to determine associations. Antibody frequencies were compared using the McNemar test.

Anti-CCP2 antibodies were found in $11 / 201$ (5.5\%) patients, anti-pepA antibodies $3(1.5 \%)$ patients, and antipepB antibodies in $5(2.5 \%)$ patients. Table 1 shows the characteristics of patients positive for ACPA. Anti-CCP2 antibodies were significantly more frequent then anti-pepA antibodies $(p=0.008)$, but not anti-pepB antibodies $(p=0.109)$. It is important to notice that in an independent control cohort all three ACPA obtained comparable specificities of at least $98.5 \% .^{5}$ Apparently, the different substrates behave differently in SLE. RF was found in $26(12.9 \%)$ patients, which was significantly more frequent than antipepA $(\mathrm{p}<0.001)$, anti-pepB $(\mathrm{p}<0.001)$, and anti-CCP2 antibodies $(p=0.006)$. Although the diagnosis in the ACPA positive patients was SLE, and all fulfilled classification criteria for SLE, ${ }^{78}$ ACR criteria for $\mathrm{RA}^{10}$ were also fulfilled in
6/10 evaluable patients, with 3/10 carrying an SE allele; radiographic erosions were present in 3/7 evaluable patients.

Our data suggest that the presence of ACPA does not exclude a diagnosis of SLE. It remains to be evaluated whether ACPA in SLE predispose for a chronic RA-like arthritis in this case.

\section{ACKNOWLEDGEMENTS}

Ilse Hoffman is supported by a research grant from the "Bijzonder OnderzoeksFonds", Ghent University.

INNO-LIA and LIA are trademarks of Innogenetics NV, Ghent, Belgium.

\section{Authors' affiliations}

I E A Hoffman, I Peene, E M Veys, F De Keyser, Department of Rheumatology, Ghent University Hospital, Ghent, Belgium

L Cebecauer, Research Institute for Rheumatic Diseases, Piestany, Slovakia

D Isenberg, Centre For Rheumatology, University College London, London, UK

T W J Huizinga, Department of Rheumatology, Leiden University Medical Centre, Leiden, The Netherlands

A Union, L Meheus, K De Bosschere, F Hulstaert, Innogenetics NV, Ghent, Belgium

Correspondence to: Dr I Hoffman, Department of Rheumatology, Ghent University Hospital, De Pintelaan 185, 9000 Ghent, Belgium;

Ilse.Hoffman@ugent.be

Accepted 1 June 2004

\section{REFERENCES}

1 Witte T, Hartung K, Sachse C, Matthias T, Fricke M, Kalden JR, et al. Rheumatoid factors in systemic lupus erythematosus: association with clinical and laboratory parameters. Rheumatol Int 2000;19:107-11.

2 Cervera R, Khamashta MA, Font J, Sebastiani GD, Gil A, Lavilla P, et al. Systemic lupus erythematosus: clinical and immunologic patterns of disease expression in a cohort of 1000 patients. Medicine (Baltimore)

1993; $72: 113-24$. 
3 Schellekens GA, Visser H, de Jong BAW, van den Hoogen FHJ, Hazes JMW, Breedveld FC, et al. The diagnostic properties of rheumatoid arthritis antibodies recognizing a cyclic citrullinated peptide. Arthritis Rheum 2000;43:155-63.

4 Union A, Meheus L, Humbel R, Conrad K, Steiner G, Moereels H, et al. Identification of citrullinated rheumatoid arthritis-specific epitopes in natural filaggrin relevant for antifilaggrin autoantibody detection by line immunoassay. Arthritis Rheum 2002:46:1185-95.

5 De Rycke L, Peene I, Hoffman IEA, Kruithof E, Union A, Meheus L, et al. Rheumatoid factor and anti-citrullinated protein antibodies in rheumatoid arthritis: diagnostic value, associations with radiological progression rate, and extra-articular manifestations. Ann Rheum Dis 2004:63:1587-93.

6 Mediwake R, Isenberg DA, Schellekens SA, van Venrooij WJ. Use of anticitrullinated peptide and anti-RA33 antibodies in distinguishing erosive arthritis in patients with systemic lupus erythematosus and rheumatoid arthritis. Ann Rheum Dis 2001;60:67-8.

7 Tan EM, Cohen AS, Fries JF, Masi AT, McShane DJ, Rothfield NF, et al. The 1982 revised criteria for the classification of systemic lupus erythematosus. Arthritis Rheum 1982;25:1271-7.

8 Hochberg MC. Updating the American College of Rheumatology revised criteria for the classification of systemic lupus erythematosus. Arthritis Rheum 1997:40:17259.

9 Hoffman IEA, Peene I, Meheus L, Huizinga TWJ, Cebecauer L, Isenberg D, et al. Specific antinuclear antibodies are associated with clinical features in systemic lupus erythematosus. Ann Rheum Dis 2004;63:1155-8.

10 Arnett FC, Edworthy SM, Bloch DA, McShane DJ, Fries JF, Cooper NS, et al. The American Rheumatism Association 1987 revised criteria for the classification of rheumatoid arthritis. Arthritis Rheum 1988;31:315-24.

\title{
Lack of efficacy of rituximab in Felty's syndrome
}

\author{
C Sordet, J-E Gottenberg, B Hellmich, P Kieffer, X Mariette, J Sibilia
}

Ann Rheum Dis 2005;64:332-333. doi: 10.1136/ard.2004.025643

$\mathrm{F}$ elty's syndrome (FS) is defined by the coexistence of rheumatoid arthritis (RA), neutropenia, and splenomegaly. The mechanisms underlying the neutropenia of FS may involve both cellular and humoral immunity, with a possible role of granulocyte-colony stimulating factor (GCSF) antibodies. ${ }^{1}$ Various disease modifying antirheumatic drugs have been used to treat FS, but with varying success ${ }^{2}$ as this syndrome may arise in response to the excessive immune reaction found in RA. Interest has focused recently on a new biological tool in the treatment of RA, rituximab, a chimeric monoclonal antibody specific for human CD20 which targets B lymphocytes. ${ }^{3}$ Accordingly, we investigated here the safety and efficacy of rituximab in two patients presenting with active RA and severe and refractory FS.

\section{METHODS AND RESULTS}

Two men, were studied, aged 67 (patient 1) and 53 (patient 2) years, with a duration of RA of 6 and 11 years, respectively. FS had been diagnosed respectively 5 and 3 years ago, and RA remained active in both patients despite corticotherapy and respectively one (sulfasalazine) and two (sulfasalazine and methotrexate) previous disease modifying antirheumatic drugs. Anti-tumour necrosis factor treatment was not used because of neutropenia and the risk of severe infection. The absolute neutrophil count was persistently less than $0.8 \times 10^{9} / 1$ and complicated with recurrent sinopulmonary infections. There was no suggestion of congenital hypogammaglobulinaemia and, in particular, no sign of selective IgG2 immunodeficiency. Blood and bone marrow immunophenotyping did not disclose any features of myelodysplasia or lymphoproliferation, or any large granular lymphocytes. No other classical cause of neutropenia, such as toxicity, chronic infection, vitamin deficiency, or liver disease, was present. Anti-G-CSF (IgG) antibodies, which were determined by enzyme linked immunosorbent assay (ELISA), ${ }^{1}$ were detected in one patient without previous administration of haematopoietic factor (G-CSF).

Owing to the presence of refractory RA associated with severe FS, rituximab was administered as an intravenous infusion at a dose of $375 \mathrm{mg} / \mathrm{m}^{2}$ once weekly for 4 weeks. Concomitant treatment consisted of prednisone (15-20 mg/ day) for more than 12 months in both patients and methotrexate $(20 \mathrm{mg} /$ week) since March 2003 in patient 2. The duration of follow up was 6 months. Rituximab was well

Table 1 Clinical and biological features of two patients with FS treated with rituximab

\begin{tabular}{|c|c|c|c|c|c|c|c|c|c|}
\hline $\begin{array}{l}\text { Normal } \\
\text { range }\end{array}$ & $\begin{array}{l}\text { DAS28 } \\
<2.6\end{array}$ & $\begin{array}{l}\text { Neutrophil } \\
\text { count } \\
1800-7500 \\
\times 10^{9} / /\end{array}$ & $\begin{array}{l}\text { ESR } \\
<8 \mathrm{~mm} / 1 \mathrm{st} \mathrm{h}\end{array}$ & $\begin{array}{l}\text { CRP } \\
<4 \mathrm{mg} / \mathrm{l}\end{array}$ & $\begin{array}{l}\text { CD19+cells } \\
200-400 / \mathrm{mm}^{3}\end{array}$ & $\begin{array}{l}\lg G \\
7.2-14.7 \mathrm{~g} / \mathrm{l}\end{array}$ & $\begin{array}{l}\lg M \\
0.48-3.10 \mathrm{~g} / 1\end{array}$ & $\begin{array}{l}\text { RF (lgM) (ELISA) } \\
<11 \mathrm{IU} / \mathrm{ml}\end{array}$ & $\begin{array}{l}\text { lgG anti-GCSF } \\
(\text { ELISA) }<20 \mathrm{IU} / \mathrm{ml}\end{array}$ \\
\hline \multicolumn{10}{|l|}{ Patient 1} \\
\hline Wo & 6.64 & 460 & 60 & 20.5 & 149 & 11.2 & 2.63 & 12 & 28 \\
\hline W1 & 5.97 & 300 & 100 & 81.6 & 5 & 11.5 & 2.69 & 16.5 & 26 \\
\hline W2 & 7.38 & 360 & 72 & 55.6 & 1 & 11.7 & 2.5 & 11 & 26 \\
\hline w3 & 7.91 & 170 & 63 & 29.8 & 0 & 10.5 & 2.34 & ND & 21 \\
\hline W4 & 7.68 & 230 & 67 & 54.8 & 2 & 10.6 & 2.28 & 7 & ND \\
\hline W12 & 6.68 & 170 & 65 & 38.2 & 2 & 12.1 & 2.65 & ND & ND \\
\hline W24 & 6.5 & 150 & 55 & 25 & 2 & 11.5 & 2.40 & ND & ND \\
\hline \multicolumn{10}{|l|}{ Patient 2} \\
\hline Wo & 7.52 & 150 & 39 & 90.2 & 67 & 15.8 & 0.97 & 60 & 0 \\
\hline W1 & 7.13 & 150 & 56 & 191 & ND & ND & ND & ND & 0 \\
\hline W2 & 5.16 & 140 & 37 & 98.1 & ND & ND & ND & ND & 0 \\
\hline W3 & 3.73 & ND & ND & 11.6 & ND & ND & ND & ND & 0 \\
\hline W4 & 2.94 & 50 & 20 & 24.3 & 9 & 11.1 & 0.41 & 29 & 0 \\
\hline W12 & 2.92 & 140 & 14 & 18.8 & 0 & 9.5 & 0.34 & 26.5 & 0 \\
\hline W16 & 2.17 & 410 & 15 & 41.1 & 0 & 8.42 & 0.58 & 12.5 & ND \\
\hline W24 & 1.74 & 260 & 8 & 8.4 & 1 & 8.14 & 0.24 & 14 & ND \\
\hline
\end{tabular}

WO, biological data were obtained before first infusion of rituximab.

DAS28, 28 joint count Disease Activity Score; ESR, erythrocyte sedimentation rate; CRP, C reactive protein; RF, rheumatoid factor, ND, not determined. 
tolerated and efficiently controlled the clinical and biological activity of RA in patient 2, who fulfilled the American College of Rheumatology 50 response criteria and showed a marked decrease in serum levels of rheumatoid factor. However, results for FS were disappointing, because no increase in neutrophil count or modification of infection rates could be detected (table 1). In patient 1 , a decrease in neutrophil count was observed at week 12, but without any clinical anomaly. Biological controls showed no modification of levels of anti-G-CSF antibodies, no appearance of anti-granulocyte antibodies, and no large granular lymphocyte proliferation. ${ }^{4}$

\section{DISCUSSION}

Several factors might account for the lack of efficacy of rituximab in the treatment of FS. Firstly, although different autoreactive B cells may be involved in the pathology of FS, the inability of rituximab to bind to plasma cells, which are CD20 negative, might prevent it from acting on FS. Nevertheless, the efficacy of rituximab in certain conditions associated with autoantibodies is not correlated with a reduction of these antibodies, which would suggest that in addition to autoantibody production, other roles of B cells (immunoglobulins, antigen presentation, T cell cooperation) are important in the pathogenesis of such diseases. ${ }^{3}$ Secondly, a subpopulation of $\mathrm{T}$ lymphocytes having an antigranulocyte activity may exist independently of B cells in some forms of FS. ${ }^{5}$
In conclusion, the lack of efficacy of rituximab in these two patients with FS raises some important questions about the mechanisms responsible for FS and the best therapeutic strategy to adopt.

\section{Authors' affiliations}

C Sordet, J-E Gottenberg, B Hellmich, P Kieffer, X Mariette, J Sibilia, CHU Hautepierre Strasbourg, CHU Kremlin-Bicêtre, Paris 67098, France

Correspondence to: Professor J Sibilia, jean.sibilia@wanadoo.fr

Accepted 22 August 2004

\section{REFERENCES}

1 Hellmich B, Csernok E, Schatz H, Gross WL, Schnabel A. Autoantibodies against granulocyte colony-stimulating factor in Felty's syndrome and neutropenic systemic lupus erythematosus. Arthritis Rheum 2002;46:2384-91.

2 Rashba EJ, Rowe JM, Packman CH. Treatment of the neutropenia of Felty syndrome. Blood Rev 1996;10:177-84.

3 Silverman GJ, Weisman S. Rituximab therapy and autoimmune disorders: prospects for anti-B cell therapy. Arthritis Rheum 2003;48:1484-92.

4 Papadaki T, Stamatopoulos K, Anagnostopoulos A, Fassas A. Rituximabassociated immune myelopathy. Blood 2003;102:1557-8.

5 Coakley G, lqbal M, Brooks D, Panayi GS, Lanchbury JJ. CD8+ CD57+T cells from healthy elderly subjects suppress neutrophil development in vitro: implications for the neutropenia of Felty's and large granular lymphocyte syndrome. Arthritis Rheum 2000;43:834-43.

\title{
Antinuclear and antiphospholipid autoantibodies in patients with peripheral arterial occlusive disease
}

\author{
K Kroeger, H Mouradi, E Kreuzfelder, G Rudofsky, H Grosse-Wilde
}

A ccording to the Chapel Hill Consensus Conference, large peripheral arteries are only affected by giant cell vasculitis and, in rare cases, by polyarteritis nodosa. ${ }^{12}$ Vasculitis becomes apparent through involvement of typical organs (lung, kidney, skin) or raised $\mathrm{C}$ reactive protein (CRP) level or erythrocyte sedimentation rate (ESR). Thus, a specific diagnostic effort to exclude vasculitis as an underlying disease in patients with peripheral arterial occlusive disease (PAOD) may be unnecessary. On the other hand, there is increasing evidence that humoral immunity may have a role in the pathogenesis of atherosclerosis. ${ }^{129}$ Antinuclear antibodies were reported in $70 \%$ of patients with severe coronary heart disease (CHD), compared with in only $17 \%$ in the control group. ${ }^{3}$ Thus, we prospectively studied the importance of autoantibody determination in patients with symptomatic PAOD.

\section{METHODS AND RESULTS}

Six hundred and ninety eight patients (mean (SD) age 68 (10) years) referred for treatment of PAOD between 1998 and 1999 were included. In 121 patients with PAOD (aged 61 (12) years) with a low atherosclerotic risk profile, or with rarefied distal arteries without media calcinosis, or with raised ESR or CRP not due to a local infection, the following autoantibodies were determined: antinuclear antibodies (ANA) by an indirect immunofluorescence technique; antibodies against extractable nuclear antigens (Scl-70, RNP, SSA, SSB, Jo-1, SM) by western blot; double stranded DNA antibodies, antineutrophil cytoplasmic antibodies (c- and
pANCA), and antiphospholipid antibodies (cardiolipin, phosphatidylserine (APSA), and $\beta_{2}$-glycoprotein) by enzyme linked immunoassay. To stratify the importance of autoantibody determination all patients with increased autoantibody concentration were clinically and sonographically followed up for 24 (6) months for evidence of vasculitides or collagen disease. A multivariate logistic regression analysis was performed to evaluate the importance of CRP and ESR in patients with autoantibody concentrations above the appropriate reference value.

Thirty eight of the 121 patients had increased autoantibody concentrations (table 1). ANA were the most common autoantibodies detected in 14 patients followed by APSA in 11, and $\beta_{2}$-glycoprotein antibodies in 12 . Patients with increased autoantibody concentration did not differ in their PAOD stages and affected segments, but in patients with increased autoantibody concentrations the ESR was higher $(\mathrm{p}=0.0043)$. The ESR at 2 hours was associated with an odds ratio of 7.1 (95\% confidence interval 1.5 to 33.8 ) in determination of increased autoantibody concentrations. During the follow up of 24 (6) months no vasculitides or collagen diseases could be detected by clinical examination or by nailfold capillary microscopy, pulmonary or gastrointestinal imaging in the 38 patients.

\section{DISCUSSION}

The group of 121 patients with PAOD analysed is a group selected individually from all the patients, but represents those patients in whom possible vasculitis may be present. 
Table 1 Characteristics of patients

\begin{tabular}{|c|c|c|c|}
\hline \multirow[b]{2}{*}{ Characteristics } & \multirow[b]{2}{*}{$\begin{array}{l}\text { No autoantibody } \\
\text { determination }\end{array}$} & \multicolumn{2}{|c|}{ Autoantibody determination } \\
\hline & & $\begin{array}{l}\text { No increased } \\
\text { autoantibodies }\end{array}$ & $\begin{array}{l}\text { Increased } \\
\text { autoantibodies }\end{array}$ \\
\hline Number & 577 & 83 & 38 \\
\hline Age (years), mean (SD) & $68(10)$ & $61(12)$ & $59(14)$ \\
\hline \multicolumn{4}{|l|}{ PAOD: } \\
\hline Stage II & 74 & 63 & 58 \\
\hline Stage III & 5 & 4 & 9 \\
\hline Stage IV & 21 & 33 & 33 \\
\hline \multicolumn{4}{|c|}{ Segment of vascular lesions: } \\
\hline Crural & 8 & 22 & 24 \\
\hline Femoral & 41 & 30 & 31 \\
\hline Iliacal & 9 & 5 & 8 \\
\hline Combined & 42 & 43 & 37 \\
\hline \multicolumn{4}{|l|}{ Risk factors: } \\
\hline Diabetes mellitus & 37 & 26 & 10 \\
\hline Hypertension & 50 & 39 & 30 \\
\hline Dyslipoproteinaemia & 66 & 41 & 28 \\
\hline Nicotine abuse & 75 & 27 & 35 \\
\hline \multicolumn{4}{|l|}{ Markers of inflammation } \\
\hline $\mathrm{ESR}>20 \mathrm{~mm} / 1 \mathrm{st} \mathrm{h}$ & 31 & 29 & $61^{*}$ \\
\hline $\mathrm{ESR}>40 \mathrm{~mm} / 2 \mathrm{nd} \mathrm{h}$ & 32 & 30 & $61^{*}$ \\
\hline CRP $>10 \mathrm{mg} / \mathrm{l}$ & 20 & 37 & 50 \\
\hline History of CHD & 47 & 17 & 16 \\
\hline
\end{tabular}

Raised concentrations of autoantibodies were common in the patients investigated. Increased autoantibody concentrations significantly correlated with a raised ESR.

As far as we know, our data are the first to report the results of autoantibody determinations in a large group of patients with PAOD. In contrast with the high rate of ANA in patients with coronary atherosclerosis, ${ }^{6-8}$ the prevalence of ANA in our patients with PAOD was much lower. Whether this difference in the prevalence of ANA was due to different forms of atherosclerosis, or due to specific differences in coronary and peripheral manifestations can only be speculated.

In agreement with the coronary studies, no association of the determined autoantibodies with classical risk factors was found. The higher ESR in the patients with increased autoantibody concentrations might be associated with a higher degree of inflammatory activity of the atherosclerosis. Antiphospholipid and $\beta_{2}$-glycoprotein antibodies, which are most relevant in association with atherosclerosis, did not seem to lead to a prognosis, ${ }^{7-9}$ but antibody determination in larger groups of non-selected patients is desirable.

\section{Authors' affiliation}

K Kroeger, H Mouradi, G Rudofsky, Department of Angiology, University of Essen, Germany

E Kreuzfelder, H Grosse-Wilde, Institute of Immunology, University of Essen, Germany
Correspondence to: Dr K Kröger, Department of Angiology, University Hospital Essen, Hufelandstrasse 55, 45122 Essen, Germany; knut.kroeger@uni-essen.de

Accepted 19 April 2004

Published Online First 21 April 2004

\section{REFERENCES}

1 Hunder GG, Arend WP, Bloch DA, Calabrese JH, Fauci AS, Fries JF, et al. The American College of Rheumatology 1990 criteria for classification of vasculitis. Arthritis Rheum 1990;33:1065-7.

2 Jennette CJ, Falk RJ, Andrassy K, Bacon PA, Churg J, Gross WL, et al. Nomenclature of systemic vasculitides: proposal of an international consensus conference. Arthritis Rheum 1994;37:187-92.

3 Farhey $Y$, Hess EV. Accelerated atherosclerosis and coronary disease in SLE. Lupus 1997:6:572-7.

4 George J, Harats D, Gilburd B, Shoenfeld Y. Emerging cross-regulatory roles of immunity and autoimmunity in atherosclerosis. Immunol Res $1996 ; 15: 315-22$

5 Wick G, Schett G, Amberger A, Setitz CS, Michaelis D, Metzler B. Is atherosclerosis an immunologically mediated disease? Immunol Today 1995; 16:27-33

6 Grainger DJ, Bethell HWL. High titres of serum antinuclear antibodies, mostly directed against nucleolar antigens, are associated with the presence of coronary atherosclerosis. Ann Rheum Dis 2002;61:110-14.

7 Sherer Y, Tenenbaum A, Praprotnik S, Shemesh J, Blank M, Fisman EZ, et al. Coronary artery diseases but not coronary calcification is associated with elevated levels of cardiolipin, beta-2-glycoprotien-I and oxidized LDL antibodies. Cardiology 2001;95:20-4.

8 Sherer Y, Tenenbaum A, Praprotnik S, Shemesh J, Blank M, Fisman EZ, et al. Autoantibodies to cardiolipin and beta-2-glycoprotien-I in coronary artery disease patients with and without hypertension. Cardiology 2002;97:2-5.

9 Limaye V, Beltrame J, Cook R, Gillis D, Pile K. Evaluation of antibodies to beta2-glycoprotein-l in the causation of coronary atherosclerosis as part of the antiphospholipid syndrome. Aust N Z J Med 1999;29:789-93. 


\title{
Incidence of primary systemic vasculitides in Vilnius: a university hospital population based study
}

\author{
J Dadoniene, G Kirdaite, Z Mackiewicz, A Rimkevicius, G Haugeberg
}

Ann Rheum Dis 2005;64:335-336. doi: 10.1136/ard.2004.022335

A s knowledge of the epidemiology of primary systemic vasculitides (PSV) is fragmentary, we attempted to investigate the incidence of temporal arteritis (TA), Takayasu's arteritis (TAA), polyarteritis nodosa (PAN), Wegener's granulomatosis (WG), Churg-Strauss syndrome (CSS), Henoch-Schönlein purpura (HSP), and hypersensitivity vasculitis (HSV) in Vilnius according to the American College of Rheumatology (ACR) 1990 criteria and to compare the data with the results from selected European studies. ${ }^{1}$

To be included in this study the patients had to $(a)$ have been diagnosed with systemic vasculitides in the 10 year period from 1990 to 1999 and $(b)$ have been resident in Vilnius at the time of diagnosis. Patients referred to Vilnius University Hospital rheumatology department were prospectively included in the study. Also, the patients' registration books from tertiary nephrology, dermatology, and internal medicine departments were searched for a diagnosis of PSV retrospectively, but following the same inclusion criteria. Additionally, the data files of the centre of pathology available from 1995 onwards, including renal register, were searched.

We applied ACR 1990 criteria for the classification of PSV; however, for patients classified as HSV, the term cutaneous leucocytoclastic vasculitis (LCV) was equally used. ${ }^{2}$ Patients with microscopic polyangiitis (MPA) were included in the PAN group, and PAN criteria applied to both conditions. The group of PAN and HSV/LCV were reanalysed according the definition for MPA. The denominator population was the adult population over 16 years from Vilnius city, which comprised 468504 people (53.7\% female) in 1999.

Table 1 Number and annual incidence (per million inhabitants) of primary systemic vasculitides in Vilnius compared with the selected European studies conducted during the past decade

\begin{tabular}{|c|c|c|c|c|}
\hline & $\begin{array}{l}\text { Vilnius, Lithuania } \\
\text { 1990-1999 }\end{array}$ & $\begin{array}{l}\text { Kristiansand, } \\
\text { Norwayt } \\
\text { 1992-1996 }\end{array}$ & $\begin{array}{l}\text { Norwich, Norfolk } \\
\text { 1988-1994 }\end{array}$ & $\begin{array}{l}\text { Lugo, Spain } \\
\text { 1988-1997 }\end{array}$ \\
\hline \multicolumn{5}{|c|}{ Giant (temporal arteritis) cell arteritis } \\
\hline Number of patients & 11 & 24 & - & 110 \\
\hline Median age in years (range) & $70(50-87)$ & & & \\
\hline Overall annual incidence & $2.3 / 10^{6 *}$ & $31.9 / 10^{6}$ & & $45.6 / 10^{6}$ \\
\hline \multicolumn{5}{|l|}{ Takayasu arteritis } \\
\hline Number of patients & 6 & 0 & 0 & 0 \\
\hline Median age in years (range) & $40(16-49)$ & & & \\
\hline Overall annual incidence & $1.3 / 10^{6}$ & & & \\
\hline \multicolumn{5}{|l|}{ Polyarteritis nodosa } \\
\hline Number of patients & & 5 & $33 \ddagger$ & 13 \\
\hline Median age in years (range) & $48(17-72)$ & & & \\
\hline Overall annual incidence & $7.7 / 10^{6}$ & $6.7 / 10^{6}$ & $8.0 / 10^{6}$ & $6.9 / 10^{6}$ \\
\hline \multicolumn{5}{|c|}{ Hypersensitivity vasculitis/cutaneous leucocytoclastic angiitis } \\
\hline Number of patients & 122 & 2 & 37 & 56 \\
\hline Median age in years (range) & $45(17-85)$ & & & \\
\hline Overall annual incidence & $26.0 / 10^{6}$ & $2.7 / 10^{6}$ & $17.8 / 10^{6}$ & $29.7 / 10^{6}$ \\
\hline \multicolumn{5}{|l|}{ Henoch-Schönlein purpura } \\
\hline Number of patients & & 3 & 3 & 27 \\
\hline Median age in years (range) & $18(16-21)$ & & & \\
\hline Overall annual incidence & $3.0 / 10^{6}$ & $6.7 / 10^{6}$ & $1.2 / 10^{6}$ & $14.0 / 10^{6}$ \\
\hline \multicolumn{5}{|l|}{ Churg-Strauss syndrome } \\
\hline Number of patients & 6 & 2 & 6 & 2 \\
\hline Median age in years (range) & $43(27-58)$ & & & \\
\hline Overall annual incidence & $1.3 / 10^{6}$ & $2.7 / 10^{6}$ & $2.4 / 10^{6}$ & $1.1 / 10^{6}$ \\
\hline \multicolumn{5}{|l|}{ Wegener's granulomatosis } \\
\hline Number of patients & & 5 & 21 & 9 \\
\hline Median age in years (range) & $57(22-68)$ & & & \\
\hline Overall annual incidence & $2.1 / 10^{6}$ & $6.7 / 10^{6}$ & $8.5 / 10^{6}$ & $4.8 / 10^{6}$ \\
\hline
\end{tabular}

*7.2/million (95\% Cl 3.8 to 13.3) for the population aged 50 years and older; toverall, 150000 adult inhabitants in the Kristiansand study, 414500 in the Norwich study, 250000 in the Lugo study, 468504 in Vilnius refer to the study period; fpolyarteritis nodosa and hypersensitivity vasculitis in this study are reported for the period from 1988 to $1997^{3}$ and from 1990 to $1994,{ }^{4}$ respectively. 
Overall, we identified 205 patients according to inclusion criteria-an annual incidence of $43.8 / 10^{6}$ (95\% confidence interval (CI) 38.1 to 50.3) (table 1). The most common type of vasculitis was HSV/LCV with an annual incidence of 26.0/10 (95\% CI 21.7 to 31.2). The incidence of PAN was found to be $7.7 / 10^{6}$ (95\% CI 5.5 to 10.7 ), HSP $3.0 / 10^{6}$ (95\% CI 1.7 to 5.1 ), TA $2.3 / 10^{6}$ (95\% CI 1.2 to 4.3 ), WG $2.1 / 10^{6}$ (95\% CI 1.1 to 4.1 ), TAA $1.3 / 10^{6}$ (95\% CI 0.5 to 2.9 ), and CSS $1.3 / 10^{6}$ (95\% CI 0.5 to 2.9) annually. Six patients in the PAN group and eight in the HCV/LCV group responded to the definition of MPA being antineutrophil cytoplasmic antibody (ANCA) positive and/or having nephritis in addition to other system involvement. Therefore, the annual incidence of presumed MPA was 3.0/ $10^{6}$ (95\% CI 2.0 to 5.7 ) in total. The diagnoses of $66 / 205$ patients were supported by biopsy data. Five of 36 patients with PAN, 8/10 patients with WG, and 4/5 with CSS were found to be ANCA positive.

Three studies, Kristiansand (Norway), ${ }^{5}$ Norwich (Norfolk, England $)^{346}$, and Lugo (Spain $)^{7}$ were selected for comparison with our study (table 1). The annual incidence of PSV in Vilnius seems to fall in between the figures of annual incidence reported in Norwich $\left(38.6 / 10^{6}\right.$, TA excluded), Kristiansand $\left(54.5 / 10^{6}\right)$, and Lugo $\left(115.0 / 10^{6}\right)$. However, the distribution of the annual incidence of distinct vasculitides differs from those of other European studies. The most important difference was noted for TA and less notably for WG (table 1). The annual incidence of MPA was in accordance with the lower figures reported in the European studies and less than half that quoted in the study by Watts et al. ${ }^{3}$

The shorter life expectancy of Lithuanian people, which in 1999 was 71 years and lower than that of the European population, might be a potential explanatory factor for the lower incidence of TA in Vilnius. Possibly, because a histological examination was rarely carried out, and the ANCA test was introduced only after $1995,{ }^{8}$ WG and other
ANCA associated vasculitides cases are underrepresented, especially in the first 5 years of this study.

\section{Authors' affiliations}

J Dadoniene, G Kirdaite, Z Mackiewicz, A Rimkevicius, Institute of Experimental and Clinical Medicine at Vilnius University, Lithuania

J Dadoniene, Vilnius University Faculty of Medicine, Vilnius, Lithuania

G Haugeberg, Sorlandet Hospital, Kristiansand, Norway

Z Mackiewicz, Department of Cell Biology, University of Opole, Poland

Correspondence to: Associate Professor J Dadoniene, Institute of Experimental and Clinical Medicine at Vilnius University, Vilnius, Lithuania, Zygimantu 9, Vilnius, LT-2600;

jolanta.dadoniene@ekmi.vu.lt

Accepted 27 April 2004

\section{REFERENCES}

1 Hunder GG, Arend WP, Bloch DA, Calabrese LH, Fauci AS, Fries JF, et al. The American College of Rheumatology 1990 criteria for the classification of vasculitis. Introduction. Arthritis Rheum 1990;33:1065-7.

2 Jennette JC, Falk RJ, Andrassy K, Bacon PA, Churg J, Gross WL, et al. Nomenclature of systemic vasculitides: proposal of an international consensus conference. Arthritis Rheum 1994;37:187-92

3 Watts RA, Lane SE, Bentham G, Scott DG. Epidemiology of systemic vasculitis. Arthritis Rheum 2000;43:414-19.

4 Watts RA, Jolliffe A, Grattan CEH, Elliott J, Lockwood M, Scott DGI. Cutaneous vasculitis in a defined population - clinical and epidemiological associations. $J$ Rheumatol 1998;25:920-2.

5 Haugeberg G, Bie R, Bendvold A, Storm Larsen A, Johsen V. Primary vasculitis in a Norwegian community hospital: a retrospective study. Clin Rheumatol $1998 ; 17: 364-8$.

6 Watts RA, Carruthers DM, Scott DGI. Epidemiology of systemic vasculitis: changing incidence or definition? Semin Arthritis Rheum 1995;25:28-34.

7 Gonzalez-Gay MA, Garcia-Porrua C. Systemic vasculitis in adults in northwest Spain, 1998-1997. Clinical and epidemiological aspects. Medicine (Baltimore) 1999;78:292-308.

8 Dadoniene J. Vasculitides and other rare rheumatic disorders. Vilnius: Vilnius University Publishing House, 2004.

\title{
Bone mineral density in patients with rheumatoid arthritis treated with infliximab
}

\author{
M Vis, A E Voskuyl, G J Wolbink, B A C Dijkmans, W F Lems for the OSTRA study group
}

Ann Rheum Dis 2005;64:336-337. doi: 10.1136/ard.2003.017780

$\mathrm{O}$ steoporosis is a well known feature of rheumatoid arthritis (RA). ${ }^{1}$ Cross sectional studies have shown that patients with RA have a lower bone mineral density (BMD) than healthy controls. ${ }^{2}$ Disease activity, steroid use, and immobility are associated with loss of $\mathrm{BMD}$ in RA. ${ }^{3-7}$ It has been suggested that active treatment of patients with RA may prevent loss of BMD. ${ }^{8}$ The current most effective drugs in the treatment of RA are the tumour necrosis factor $\alpha$ blocking agents. The beneficial effects of short term treatment with infliximab on markers of bone metabolism in patients with active RA have recently been shown. ${ }^{9}$ From this we proposed the hypothesis that bone loss might be arrested in patients with RA during treatment with infliximab.

\section{METHODS AND RESULTS}

This open cohort study consisted of consecutive patients with RA, who were treated with infliximab in the Slotervaart Hospital and the VU University Medical Centre. All patients fulfilled the ACR 1987 criteria of RA and had active disease (defined by the modified 28 joint count Disease Activity Score (DAS28) of at least 3.2). Infliximab was given intravenously at $0,2,6,14$, weeks and from the fourth infusion every 8 weeks in a dose of $3 \mathrm{mg} / \mathrm{kg}$. At each visit the DAS28 was calculated and changes in drug treatment were recorded. BMD measurements $\left(\mathrm{g} / \mathrm{cm}^{2}\right)$ of the hip (total hip) and lumbar spine (Ll-4) were performed at baseline and after 1 year on a Hologic 4500 . 
Table 1 Summary of changes in BMD of five studies in patients with RA

\begin{tabular}{|c|c|c|c|c|c|}
\hline \multirow[b]{2}{*}{ Study } & \multirow{2}{*}{$\begin{array}{l}\text { Patients } \\
\text { (n) }\end{array}$} & \multirow[b]{2}{*}{ RA } & \multirow{2}{*}{$\begin{array}{l}\text { Follow up } \\
\text { (years) }\end{array}$} & \multicolumn{2}{|c|}{ BMD change (\%) } \\
\hline & & & & Hip & Spine \\
\hline Boers $^{10} \ddagger$ & 62 & Early & 1 & -1.3 & -0.3 \\
\hline Gough $^{5}$ & 50 & Early & 1 & -4.2 & -2.4 \\
\hline Haugeberg $^{3}$ & 366 & Established & 2 & -0.77 & -0.29 \\
\hline Dolan $^{8}$ & 21 & Established & 2 & $0.0^{*}$ & $-1.02^{*}$ \\
\hline Shibuya ${ }^{2}$ & 146 & Established & 1 & No data† & $-1.1^{*}$ \\
\hline This study & 36 & Established & 1 & -0.3 & +1.1 \\
\hline
\end{tabular}

In total, 36 patients (29 (81\%) female) were included into the study. Patients had a mean (SD) age of 53 (12) years, with a median (range) disease duration of 9.5 years (0-49). Methotrexate, prednisone, and bisphophonates were used by $100 \%, 50 \%$, and $25 \%$ of the patients, respectively. The mean disease activity (DAS28) decreased from 5.6 at baseline to 3.8 at 6 weeks and stabilised around 3.6 for the rest of the studied period. In 36 patients dual $x$ ray absorptiometry (DXA) measurements of lumbar spine ( $\mathrm{Ll}-4)$ and in 30 patients DXA measurements of the hip were available at baseline and after 1 year. In four patients no DXA hip measurements were available because of bilateral hip replacement, and in two patients only one DXA of the hip was available owing to unknown causes.

Mean (SD) BMD at the lumbar spine increased nonsignificantly from $0.998(0.205)$ to $1.001(0.199)$ at 1 year $(+1.1 \%, \mathrm{p}=0.117)$. BMD at the total hip decreased nonsignificantly from $0.857(0.144)$ to $0.854(0.132)$ at 1 year. $(-0.3 \%, p=0.683)$. In a linear regression model, changes in BMD at the hip or the spine were not associated with mean DAS28, prednisone use, or bisphosphonate use (data not shown).

\section{DISCUSSION}

This study indicates that BMD of the spine has a tendency to increase and that BMD of the hip slightly decreases during 1 year of treatment with infliximab. This is in contrast with previous longitudinal studies of patients with RA, in which a decrease of BMD was seen during conventional disease modifying antirheumatic drug treatment without tumour necrosis factor blockings agents (table 1 ).

In our view, these data suggest that treatment with infliximab can arrest generalised osteoporosis in patients with RA. This view is supported by the observation that markers of bone formation increased and markers of bone resorption decreased in the first 6 weeks of treatment with infliximab. ${ }^{7}$ We do realise that our observations are made in an open cohort study and therefore no definite conclusions can be drawn from our data.

In summary, this study suggests that treatment with infliximab has a positive effect on BMD in patients with RA. Because patients with RA have an increased risk of bone loss and, subsequently, osteoporotic fractures, this might be an additional advantage of infliximab (above the well known favourable effect on disease activity and radiological damage), and warrants further study.

\section{ACKNOWLEDGEMENTS}

We thank the members of the OSTRA group: TK Kvien, G Haugeberg, T Uhlig, EA Haavardsholm (Oslo, Norway), and A Woolf (Truro, UK), for their valuable comments.

\section{Authors' affiliations}

M Vis, A E Voskuyl, G J Wolbink, B A C Dijkmans, W F Lems, Department of Rheumatology, VU University Medical Centre, Amsterdam, The Netherlands

M Vis, B A C Dijkmans, W F Lems, Slotervaart Hospital, Amsterdam, The Netherlands

Correspondence to: DrM Vis, Department of Rheumatology, 4A 42, VU University Medical Centre, Postbus 7057, 1007 MB Amsterdam, The

Netherlands; m.vis@vumc.nl

Accepted 20 June 2004

\section{REFERENCES}

1 Kvien TK, Haugeberg G, Uhlig T, Falch JA, Halse Jl, Lems WF, et al. Data driven attempt to create a clinical algorithm for identification of women with rheumatoid arthritis at high risk of osteoporosis. Ann Rheum Dis 2000;59:805-11.

2 Shibuya K, Hagino H, Morio Y Teshima R. Cross-sectional and longitudinal study of osteoporosis in patients wit rheumatoid arthritis. Clin Rheumatol 2002:150-8.

3 Haugeberg G, Uhlig T, Falch JA, Halse JI, Kvien TK. Bone mineral density and frequency of osteoporosis in female patients with RA: results from 394 patients in Oslo. Arthritis Rheum 2000;43:522-30.

4 Lodder MC, Haugeberg G, Lems, Uhlig T, Orstavik RE, Kostense PJ, et al. Radiographic damage associated with low bone mineral density and vertebral deformities in rheumatoid arthritis: the Oslo-Truro-Amsterdam (OSTRA) collaborative study. Arthritis Rheum 2003;49:209-15.

5 Gough AK, Lilley J, Eyre S, Holder RL, Emery P. Generalized bone loss in patients with early rheumatoid arthritis. Lancet 1994;344:23-7.

6 Cortet B, Guyot MH, Solau E, Pigny P, Dumoulin F, Flipo RM, et al. Factors influencing bone loss in rheumatoid arthritis: a longitudinal study. Clin Exp Rheumatol 2000;18:683-90.

7 Gough AK, Peel NF, Eastell R, Holder RL, Lilley J, Emery P. Excretion of pyridium crosslinks correlates with disease activity and appendicular bone loss in early rheumatoid arthritis. Ann Rheum Dis 1994;53:14-17.

8 Dolan AL, Moniz C, Abraha H, Pitt P. Does active treatment of rheumatoid arthritis limit disease-associated bone loss? Rheumatology (Oxford) 2002;41:1047-51.

9 Vis M, Wolbink G, Lodder MC, Kostense PJ, Van De Stadt RJ, De Koning, et al. Early changes in bone metabolism in rheumatoid arthritis patients treated with infliximab. Arthritis Rheum 2003;48:2996-7.

10 Boers M, Verhoeven AC, Markusse HM, van de Laar MA, Westhovens R, van Denderen JC, et al. Randomised comparison of combined step-down prednisolone, methotrexate and sulphasalazine with sulphasalazine alone in early rheumatoid arthritis. Lancet 1997;350:309-18. 


\title{
An open study of pulse pamidronate treatment in severe ankylosing spondylitis, and its effect on biochemical markers of bone turnover
}

\author{
A P Cairns, S A Wright, A J Taggart, S M Coward, G D Wright
}$$
\text { (............................ }
$$

Ann Rheum Dis 2005;64:338-339. doi: 10.1136/ard.2004.022871

O steoporosis is a common feature of ankylosing spondylitis (AS), and vertebral fractures are an increasingly recognised complication. A cumulative fracture prevalence of between $9.5 \%$ and $18 \%$ has been reported, with a six- to eightfold relative increased risk of vertebral fracture. ${ }^{1-3}$ Osteoporosis and new bone formation (syndesmophytosis) suggest that disordered bone turnover has a role in disease pathogenesis in AS. Bisphosphonates accumulate at sites of increased bone turnover, and inhibit bone resorption by inducing osteoclast apoptosis, ${ }^{4}$ thereby improving bone density and reducing fracture rates. ${ }^{5}$ Pulse pamidronate has recently been used with clinical efficacy in the treatment of AS. ${ }^{67}$ Biochemical markers of bone turnover have been used to monitor response to treatment in postmenopausal osteoporosis. ${ }^{8}$

The effect of bisphosphonate treatment on biochemical bone turnover markers has not previously been studied in AS. We aimed at studying the efficacy of pulse pamidronate treatment in severe AS, and at determining its effect on biochemical bone turnover markers.

\section{METHODS AND RESULTS}

Patients with severe AS were treated with 6 monthly intravenous pulses of pamidronate, receiving $30 \mathrm{mg}$ for the first infusion and $60 \mathrm{mg}$ subsequently. The Bath AS Disease Activity Index (BASDAI) and the Bath AS Metrology Index (BASMI) scores were recorded, and $\mathrm{C}$ reactive protein (CRP) and erythrocyte sedimentation rate (ESR) measured at each visit. Fifteen patients participated ( 13 male, mean age 44 ). Mean disease duration was 14.8 years. All patients were receiving non-steroidal anti-inflammatory drugs; two were also receiving sulfasalazine, one methotrexate, and one azathioprine. No patients were currently receiving an oral bisphosphonate. Four patients had a history of uveitis, two psoriasis, two inflammatory bowel disease, and eight peripheral arthritis.

Fasting blood samples were taken monthly for measurement of biochemical bone turnover markers, according to the manufacturers' instructions. Degradation products of type I collagen C-terminal telopeptides were measured with the serum crosslaps enzyme linked immunosorbent assay (ELISA; Nordic Bioscience Diagnostics A/S, Herlev, Denmark). Serum bone GLA protein was measured using the N-MID osteocalcin ELISA kit (Nordic Bioscience Diagnostics A/S, Herlev, Denmark). Bone-specific alkaline phosphatase was measured with the Access Ostase assay (Beckman Coulter Inc, Fullerton, California, USA). Nonparametric analyses (Wilcoxon signed rank tests) on an intention to treat basis were used to analyse the data.

Three patients did not complete the study (arthralgia/ headache, back pain/nausea, and myalgia, respectively). The mean total dose of pamidronate received was $277 \mathrm{mg}$. The initial median serum crosslaps was $1845.0 \mathrm{ng} / \mathrm{ml}$. Mean (SD) population serum crosslaps concentrations are 506 (255) ng/l for postmenopausal women, 321 (155) ng/l for premenopausal women, and 332 (190) ng/l for men. The initial median ostase concentration was $12.4 \mu \mathrm{g} / \mathrm{l}$. Mean (SD) population ostase concentrations are $12.3(4.3) \mu \mathrm{g} / \mathrm{l}$ for men, 8.7 (2.9) $\mu \mathrm{g} / \mathrm{l}$ for premenopausal women, and 13.2 (4.7) $\mu \mathrm{g} / \mathrm{l}$ for postmenopausal women. The initial median osteocalcin concentration was $19.5 \mathrm{ng} / \mathrm{ml}$. Mean (SD) population osteocalcin concentrations are 17.9 (6.5) ng/ml for premenopausal women, $28.4(9.5) \mathrm{ng} / \mathrm{ml}$ for postmenopausal women, and $21.4(9.1) \mathrm{ng} / \mathrm{ml}$ for men.

Median serum crosslaps fell from 1845.0 to $556.5 \mathrm{ngl} / \mathrm{l}$ $(\mathrm{Z}=-3.29, \mathrm{p}=0.001$ ) (fig $\mathrm{l})$. Median serum osteocalcin fell from 19.5 to $16.2 \mathrm{ng} / \mathrm{ml}(\mathrm{Z}=-2.34, \mathrm{p}=0.02)$. Median serum ostase fell from 12.4 to $9.6 \mu \mathrm{g} / \mathrm{l}(\mathrm{Z}=-3.11, \mathrm{p}=0.02)$. The median BASDAI improved from 6.80 to $5.75(\mathrm{Z}=-1.98$, $p=0.048)$, but there was no significant improvement in the median BASMI (initial $8.00 v$ final 7.50, $\mathrm{Z}=-1.64, \mathrm{p}=0.10$ ). There were non-significant trends of reduction in median CRP (initial $36.4 v$ final $26.6 \mathrm{mg} / \mathrm{l}, \mathrm{Z}=-1.89, \mathrm{p}=0.06$ ) and median ESR (initial $38 v$ final $29 \mathrm{~mm} / \mathrm{lst} \mathrm{h}, \mathrm{Z}=-0.7 \mathrm{l}$, $\mathrm{p}=0.48$ ). There were no significant correlations between clinical measures and bone turnover markers.

\section{DISCUSSION}

Pulse pamidronate treatment significantly reduced all three biochemical bone turnover markers. This was particularly marked for serum crosslaps, the bone resorptive marker, where there was a $69.8 \%$ relative reduction. Such marked reduction of the crosslaps concentration suggests that bisphosphonates have a role in the management of the osteoporosis of AS. Ultimately, studies assessing fracture rates in patients with AS receiving bisphosphonates would be of great interest. One possibility is that by reducing the rate of new bone formation, bisphosphonates may also reduce syndesmophyte formation. However, longer term controlled

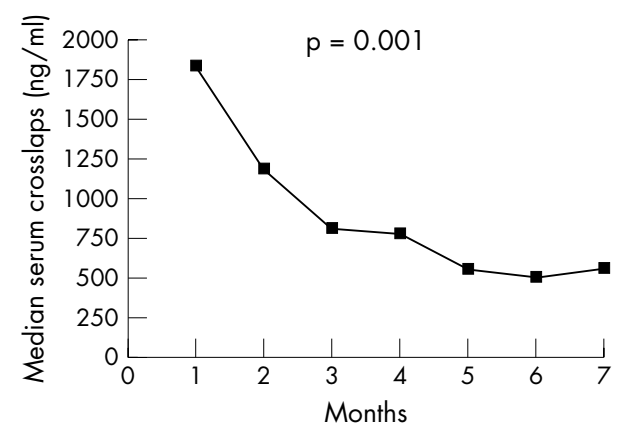

Figure 1 Median serum crosslaps values. 
studies in patients with early disease are needed to examine this subject.

Pulse pamidronate treatment also had a small beneficial effect on disease activity as measured by the BASDAI, which has also been demonstrated in a recent randomised controlled study of pamidronate treatment in AS. $^{7}$ The patients in our study had established, severe disease. All but one would have met recent ASAS criteria for the use of anti-tumour necrosis factor drugs in AS. ${ }^{9}$ Clinical studies in earlier, less severe disease are required to determine if bisphosphonates may be of benefit to these patients.

\section{Authors' affiliations}

A P Cairns, S A Wright, A J Taggart, G D Wright, Department of Rheumatology, Musgrave Park Hospital, Belfast, Northern Ireland, UK S M Coward, Department of Biochemistry, Musgrave Park Hospital, Belfast, Northern Ireland, UK

Correspondence to: Dr A Cairns, Department of Rheumatology, Musgrave Park Hospital, Belfast BT9 7JB, UK;

andrewcairns@doctors.org.uk

\section{REFERENCES}

1 Cooper C, Carbone L, Michet CJ, Atkinson EJ, O'Fallon WM, Melton U 3rd. racture risk in patients with ankylosing spondylitis: a population based study. J Rheumatol 1994;21:1877-82.

2 Mitra D, Elvins DM, Speden DJ, Collins AJ. The prevalence of vertebral fractures in mild ankylosing spondylitis and their relationship to bone mineral density. Rheumatology (Oxford) 2000;39:85-9.

3 Ralston SH, Urquart GDK, Brzeski M, Sturrock RD. Prevalence of vertebral compression fractures due to osteoporosis in ankylosing spondylitis. BMJ 1990;300:563-5.

4 Luckman SP, Coxon FP, Ebetino FH, Russell RG, Rogers MJ. Heterocyclecontaining bisphosphonates cause apoptosis and inhibit bone resorption by preventing protein prenylation: evidence from structure-activity relationships in J774 macrophages. J Bone Miner Res 1998;13:1668-78.

5 Tuck SP, Francis RM. Osteoporosis. Postgrad Med J 2002;78:526-32.

6 Maksymowych WP, Jhangri GS, Fitzgerald AA, LeClercq S, Chiu P, Yan A, et al. A six-month randomized, controlled, double-blind, dose-response comparison of intravenous pamidronate $(60 \mathrm{mg}$ versus $10 \mathrm{mg}$ ) in the treatment of nonsteroidal antiinflammatory drug-refractory ankylosing spondylitis. Arthritis Rheum 2002;46:766-73.

7 Haibel H, Brandt J, Rudwaleit M, Soerensen H, Sieper J, Braun J. Treatment of active ankylosing spondylitis with pamidronate. Rheumatology (Oxford) 2003:42:1018-20.

8 Looker AC, Bauer DC, Chesnut CH 3rd, Gundberg CM, Hochberg MC, Klee G, et al. linical use of biochemical markers of bone remodeling: current status and future directions. Osteoporos Int 2000;11:467-80.

9 Braun J, Pham T, Sieper J, Davis J, van der Linden S, Dougados M, et al. International ASAS consensus statement for the use of anti-tumour necrosis factor agents in patients with ankylosing spondylitis. Ann Rheum Dis 2003;62:817-24.

\title{
Association between interleukin 6 gene polymorphisms and Behçet's disease in Korean people
}

\author{
H K Chang, W C Jang, S B Park, S M Han, Y H Nam, S S Lee, J U Kim, H S Lee
}

l: terleukin (IL) 6 is an important mediator of inflammatory and immune responses, and IL6 gene polymorphisms are known to play a part in chronic inflammatory and autoimmune disorders. ${ }^{12}$ Increased IL6 plasma levels and enhanced IL6 mRNA expression have been found in patients with active Behçet's disease. ${ }^{3}$ Therefore, this study aimed at investigating the associations between Behçet's disease in Korean people and two functional IL6 gene polymorphismsnamely, a single nucleotide polymorphism at $-174(\mathrm{G} \rightarrow \mathrm{C})$ in the IL6 gene promoter (IL6prom) and a variable number of tandem repeat polymorphisms in the $3^{\prime}$ flanking region of the IL6 gene (IL6vntr): the terms IL6prom and IL6vntr were designated as in a previous study. ${ }^{5}$

\section{METHODS AND RESULTS}

The study group included 89 Korean patients with Behçet's disease (36 men, 53 women; mean (SD) age 39.1 (8.5)), fulfilling the International Study Group criteria, ${ }^{6}$ and 123 controls (47 men, 76 women; mean (SD) age 43.1 (13.4)). The cumulative history of severe manifestations was investigated during the disease course. ${ }^{7}$ Analyses of IL6prom and IL6vntr were carried out in all the subjects by polymerase chain reaction (PCR)-restriction fragment length polymorphism and PCR genotyping, respectively. ${ }^{18}$ Significance was evaluated using Fisher's exact test or $t$ test and defined as $\mathrm{p} \leqslant 0.05$ : $\mathrm{p}$ values with Bonferroni's correction ( $\mathrm{p}_{\text {corr }}$ ) were calculated in certain cases. Haplotype and linkage disequilibrium (LD) analyses were assessed using the estimated haplotype (EH) programme. ${ }^{9}$
There was no evidence of genetic association conferred by the IL6prom polymorphism. In the case of the IL6vitr, four genotypes were identified with the following frequencies in the controls: $\mathrm{AB}, 2$ (1.6\%); $\mathrm{BB}, 117(95.1 \%)$; BC, 3 (2.4\%); CC, 1 (0.8); and in the patients with Behçet's disease: $\mathrm{BB}, 77(86.5 \%)$; $\mathrm{BC}, 12(13.5 \%)$. Because the vast majority $(98.6 \%)$ of the subjects had one of the two common genotypes (BB and BC), comparisons between the groups were made with these major genotypes and alleles. There were significant differences in the frequencies of the IL6vitr genotypes and alleles between patients with Behçet's disease and controls (genotypes: $p=0.005$, $\mathrm{p}_{\text {corr }}=0.01$; alleles: $\left.\mathrm{p}=0.022, \mathrm{p}_{\text {corr }}=0.044\right)$ (table 1 ). The odds ratio for Behçet's disease associated with the $\mathrm{C}$ allele of IL6vntr (IL6vntr $\left.{ }^{*} \mathrm{C}\right)$ was 3.5 (95\% confidence interval 1.2 to $10.0)$.

When the studied subjects were stratified according to the results of HLA-B5I testing, significant differences in the IL6vntr genotype and allele frequencies were found only in the HLA-B5l negative subjects (genotypes: $\mathrm{p}=0.005$, $p_{\text {corr }}=0.01$; alleles: $\left.p=0.02, p_{\text {corr }}=0.04\right)$. Using the $E H$ programme, the distribution of haplotypes between patients with Behçet's disease and controls differed significantly only in those with the IL6prom ${ }^{*} \mathrm{G} / \mathrm{IL}_{\text {vnntr }}{ }^{*} \mathrm{C}$ haplotype $(\mathrm{p}=0.001$, $\left.\mathrm{p}_{\text {corr }}=0.004\right)$ : the odds ratio for Behçet's disease in the subjects with this haplotype was 7.3 (95\% confidence interval 1.6 to 32.9 ). In addition, the EH programme revealed a D value of 0.08 , suggesting the presence of $\mathrm{LD}$ at low level between the two polymorphic sites. 
Table 1 Genotype and allele frequencies of the IL6prom and the IL6vntr polymorphisms in the group with Behçet's disease $(n=89)$ and controls $(n=123)$

\begin{tabular}{lll}
\hline & $\begin{array}{l}\text { Controls } \\
\text { No }(\%)\end{array}$ & $\begin{array}{l}\text { Behçet's disease } \\
\text { No }(\%)\end{array}$ \\
\hline ILGprom & & \\
Genotype & $4(3.3)$ & $4(4.5)$ \\
GG & $119(96.7)$ & $85(95.5)^{*}$ \\
GC & $127(51.6)$ & $93(52.2)$ \\
Allele & $119(48.4)$ & $85(47.8)^{* *}$ \\
G & & \\
C & & \\
IL6vntr & $117(95.1)$ & $77(86.5)$ \\
Genotype & $3(2.4)$ & $12(13.5) \dagger$ \\
BB & $239(97.2)$ & $166(93.3)$ \\
BC & $5(2.0)$ & $12(6.7) \ddagger$ \\
Allele & & \\
C & &
\end{tabular}

${ }^{*} p=0.723$ and ${ }^{* *} p=0.922$ for comparisons of the IL6prom between the patients with Behçet's disease and controls; $\uparrow p=0.005\left(p_{\text {corr }}=0.01\right)$ and $\ddagger p=0.022$ ( $p_{\text {corr }}=0.044$ ) for comparisons of the IL 6 vntr between the patients with Behçet's disease and controls.

No significant associations were found between the genotypes of the two IL6 polymorphisms (IL6prom and IL6vntr) and clinical variables, including disease duration, mean age at onset, clinical manifestations, severe manifestations, and HLA-B51 positivity, in patients with Behçet's disease (all $\mathrm{p}>0.05$ ). However, the distribution of the IL6vntr genotype differed significantly between male and female patients, and the frequency of the BC genotype was much higher in female patients with Behçet's disease than in male patients (BB: male, $45.5 \% v$ female, $54.5 \%$; BC: male, $8.3 \% v$ female, $\left.91.7 \% ; \mathrm{p}=0.024, \mathrm{p}_{\text {corr }}=0.048\right)$.

\section{DISCUSSION}

Our data are consistent with previous investigations showing considerable interethnic variability in the distribution of the IL6prom and IL6vntr genotypes. ${ }^{12}{ }^{10}$ There was no evidence for genetic association conferred by the IL6prom polymorphism, whereas significant differences in the IL6vntr genotype and allele frequencies were found between patients with Behçet's disease and controls. These differences were particularly apparent in the HLA-B51 negative subjects or female patients. In addition, susceptibility to Behçet's disease was increased significantly in subjects carrying the IL6vntr ${ }^{*} \mathrm{C}$ allele and the IL6prom ${ }^{*} \mathrm{G} / \mathrm{IL}_{\mathrm{N}} n$ tr $^{*} \mathrm{C}$ haplotype. To confirm these findings, further investigations are required in other ethnic populations.

\section{ACKNOWLEDGEMENT}

This study was supported by grants from Institute of Life Science, Dankook University Medical Centre in 2003.

\section{Authors' affiliations}

H K Chang, Division of Rheumatology, Department of Internal Medicine, Dankook University, Cheonan, South Korea

W C Jang, S B Park, S M Han, Y H Nam, Department of Chemistry,

Dankook University, Cheonan, South Korea

S S Lee, Division of Rheumatology, Department of Internal Medicine,

Chonnam National University Medical School, Gwangju, South Korea

J U Kim, Department of Laboratory Medicine, Ulsan University,

Kangnung, South Korea

H S Lee, Division of Rheumatology, Department of Internal Medicine, Hanyang University, Kuri, South Korea

H K Chang and W C Jang contributed equally to this manuscript.

Correspondence to: Associate Professor H K Chang, Division of Rheumatology, Department of Internal Medicine, College of Medicine, Dankook University, 16-5 Anseo-Dong, Cheonan, Chungcheong Nam Do, 330-715, South Korea; hanks22@dankook.ac.kr

Accepted 21 April 2004

\section{REFERENCES}

1 Fishman D, Faulds G, Jeffery R, Mohamed-Ali V, Yudkin JS, Humphries S, et al. The effect of novel polymorphisms in the interleukin-6 (IL-6) gene on IL-6 transcription and plasma IL- 6 levels, and an association with systemic-onset juvenile chronic arthritis. J Clin Invest 1998;102:1369-76.

2 Murray RE, McGuigan F, Grant SF, Reid DM, Ralston SH. Polymorphisms of the interleukin- 6 gene are associated with bone mineral density. Bone 1997:21:89-92.

3 Hamzaoui K, Hamzaoui A, Guemira F, Bessioud M, Hamza M, Ayed K. Cytokine profile in Behçet's disease patients. Relationship with disease activity. Scand J Rheumatol 2002;31:205-10.

4 Yamakawa Y, Sugita Y, Nagatani T, Takahashi S, Yamakawa T, Tanaka S, et al. Interleukin-6 (IL-6) in patients with Behçet's disease. J Dermatol Sci 1996; 11:189-95.

5 Bagli M, Papassotiropoulos A, Knapp M, Jessen F, Luise Rao M, Maier W, et al. Association between an interleukin-6 promoter and 3' flanking region haplotype and reduced Alzheimer's disease risk in a German population. Neurosci Lett 2000;283:109-12.

6 International Study Group for Behçet's Disease. Criteria for diagnosis of Behçet's disease. Lancet 1990;335:1078-80.

7 Kim JU, Chang HK, Lee SS, Kim JW, Kim KT, Lee SW, et al. Endothelial nitric oxide synthase gene polymorphisms in Behçet's disease and rheumatic diseases with vasculitis. Ann Rheum Dis 2003;62:1083-7.

8 Bowcock AM, Ray A, Erlich H, Sehgal PB. Rapid detection and sequencing of alleles in the 3' flanking region of the interleukin-6 gene. Nucleic Acids Res $1989 ; 17: 6855-64$.

9 Zhao JH, Curtis D, Sham PC. Model-free analysis and permutation tests for allelic associations. Hum Hered 2000;50:133-9.

10 Bowcock AM, Kidd JR, Lathrop GM, Daneshvar L, May LT, Ray A, et al. The human "interferon-beta 2/hepatocyte stimulating factor/interleukin-6" gene: DNA polymorphism studies and localization to chromosome 7p21. Genomics 1988:3:8-16. 